ENVIRONMENTAL SCIENCE AND RESEARCH FOUNDATION REPORT SERIES:

NUMBER ESRF-035(2QT99)

ISSN NUMBER 1089-5469

BECEIVE:

\title{
Idaho National Engineering and Environmental Laboratory Offsite \\ OSTI Environmental Surveillance Program Report: Second Quarter 1999
}

Roy Evans

Environmental Science and Research Foundation, Inc. Doyle Markham, Executive Director

December 1999

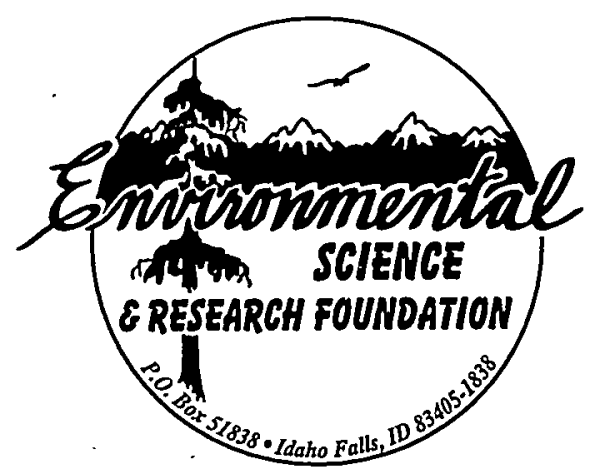

Program conducted for the U.S. Department of Energy, Idaho Operations Office Under Contract DE-AC07-94ID13268

Environmental Science and Research Foundation, Inc.

101 S. Park Avenue, Suite 2

P.O. Box 51838

Idaho Falls, Idaho $83405-1838$ 


\section{Executive Summary}

The Environmental Science and Research Foundation conducts an Offsite Environmental Surveillance Program for the Department of Energy's Idaho National Engineering and Environmental Laboratory (INEEL). The Foundation's environmental surveillance program monitors the effects, if any, of U.S. Department of Energy (DOE) activities on the offsite environment, collects data to confirm compliance with applicable environmental laws and regulations, and observes any trends in environmental levels of radioactivity. This report for the second quarter 1999 is based on 618 samples of air (including airborne radioactivity, fine particulates, and atmospheric moisture), precipitation, milk, drinking water, sheep, wild game tissues, and environmental radiation. All concentrations of radioactivity found in these samples were consistent with concentrations which have been found in sampling during recent quarters and which have been attributed in the past to natural background radiation, worldwide fallout from past nuclear weapons testing, and nuclear operations around the world. No measured concentrations could be directly attributed to operations at the INEEL. Concentrations in all samples were below the guidelines set by both the DOE and the U.S. Environmental Protection Agency (EPA) for protection of the public.

\section{Program Description}

The Foundation collected filters weekly from low-volume air samplers at 12 offsite locations. Five were at distant locations and seven were near the INEEL boundary. An additional three air samplers were operated on the INEEL. Replicate samplers were operated at two offsite boundary locations for quality assurance purposes. Weekly measurements were made of gross alpha and gross beta activity in airborne particulates. Charcoal cartridges were screened weekly for the presence of iodine-131. At the end of the quarter, weekly filters from each location were combined to form a composite sample for that location. These composites were then analyzed for gamma-emitting radionuclides. Selected composites were also submitted for analyses for strontium-90 and transuranics (plutonium-238, plutonium-239/240, and americium-241).

$\mathrm{PM}_{10}$ samplers were operated at three offsite locations to sample airborne particulates with an aerodynamic diameter smaller than 10 microns. Particles this size can penetrate the body's natural air filtering system and enter the lungs.

Atmospheric moisture and precipitation samples were collected to monitor for tritium. Atmospheric moisture samples were collected by sampling continuously for 13 weeks at each of four locations. The Foundation collected monthly precipitation samples at one onsite location and one offsite location, as well as a weekly precipitation sample at a second onsite location.

The Foundation collected a weekly milk sample from a dairy in Idaho Falls and collected monthly milk samples from eight additional dairies around the INEEL. All milk samples were analyzed for iodine- 131 .

Water samples were collected in May from 13 drinking water locations and five surface water locations in the Magic Valley and in Idaho Falls. Gross alpha and gross beta activities and tritium concentrations were determined for all samples.

Fourteen thermoluminescent dosimeters (TLDs) were collected to measure ambient gamma radiation. Six sheep were sampled in May: four from flocks which had grazed on the INEEL, and two control sheep from Blackfoot. Tissue samples of muscle, thyroid, and liver 


\section{DISCLAIMER}

This report was prepared as an account of work sponsored by an agency of the United States Government. Neither the United States Government nor any agency thereof, nor any of their employees, make any warranty, express or implied, or assumes any legal liability or responsibility for the accuracy, completeness, or usefulness of any information, apparatus, product, or process disciosed, or represents that its use would not infringe privately owned rights. Reference herein to any specific commercial product, process, or service by trade name, trademark, manufacturer, or otherwise does not necessarily constitute or imply its endorsement, recommendation, or favoring by the United States Government or any agency thereof. The views and opinions of authors expressed herein do not necessarily state or reflect those of the United States Government or any agency thereof. 


\section{DISCLAIMER}

Portions of this document may be illegible in electronic image products. Images are produced from the best available original document. 
were collected from an elk killed accidentally on INEEL roads during the quarter, and were subjected to gamma spectroscopic analysis.

For more information concerning the contents of this report, contact the Foundation at (208) 525-7102, or visit the Foundation's web page (http://esrf.org).

\section{Summary of Second Quarter 1999 Results}

During the second quarter of 1999, gross alpha and gross beta activities in low-volume air samples were within the expected range of values for background radioactivity. No statistically significant differences were found between the quarterly means of gross alpha or gross beta activities observed in samples from the INEEL, boundary, and distant stations. Iodine-131 was not found in any air sample. No transuranic radionuclides were detected in the quarterly composite samples. Small concentrations of strontium-90 detected in quarterly composite samples from Monteview and from the INEEL Main Gate were probably contributed by resuspended fallout from atmospheric weapons testing.

$\mathrm{PM}_{10}$ sampling for respirable particulates continued in three locations: Atomic City, Madison Middle School in Rexburg, and Mountain View Middle School in Blackfoot. All particulate concentrations were below all EPA guidelines.

Tritium was detected at very low concentrations in three surface water samples, although tritium was non-detectable in recounts for two of these samples. Gross alpha activity was detected in two drinking water samples. The gross alpha detections were in the questionable range between two and three sample standard deviations and were well below the DOE derived concentration guide and the U.S.EPA's drinking water standard. Three atmospheric moisture samples had detectable levels of tritium. Tritium was also found in Idaho Falls and onsite precipitation samples. The observed tritium concentrations in surface water, precipitation, and atmospheric moisture samples were well below the applicable DOE derived concentration guides and can probably be attributed to natural production by cosmic ray bombardment of the upper atmosphere. All detected concentrations were within the ranges seen in similar samples in recent quarters.

No detectable concentrations of iodine-131 were reported in the 37 milk samples collected during the second quarter.

External gamma radiation measured with TLDs was consistent with past ambient measurements and is attributable to natural background. Measured external gamma radiation at stations near the INEEL was not significantly different from measurements at distant stations.

Five of six sheep had detectable traces of cesium-137 in their muscle tissue, and four in their livers. The control samples contained levels of radionuclides not significantly different from those sheep which had grazed on site. No radionuclides were found in a road-killed elk. 


\section{Table of Contents}

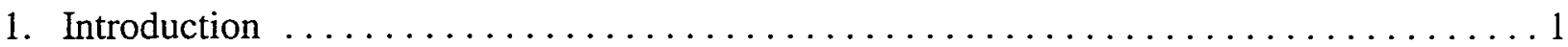

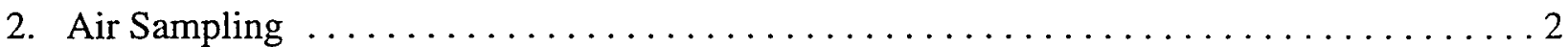

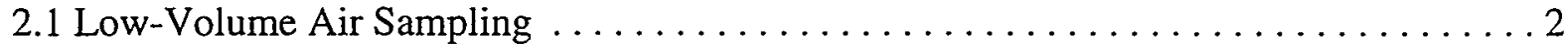

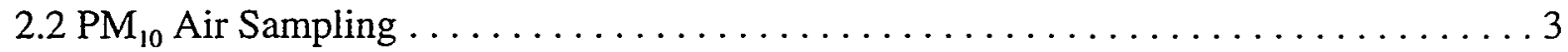

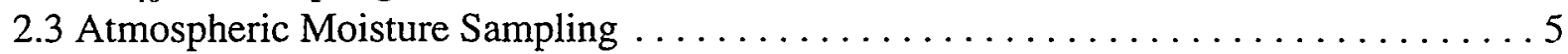

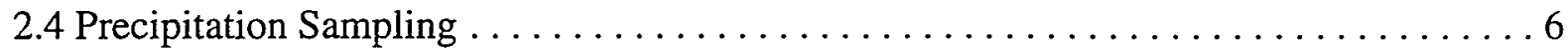

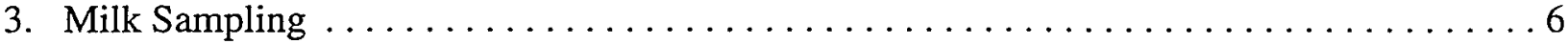

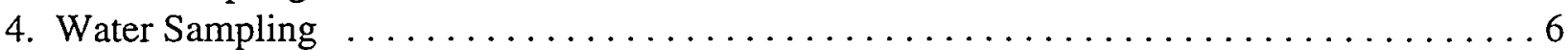

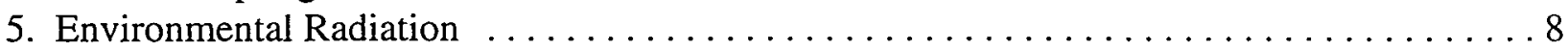

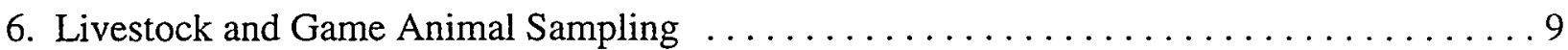

Appendix A: Summary of Environmental Surveillance Networks $\ldots \ldots \ldots \ldots \ldots \ldots \ldots 11$

Appendix B: Helpful Information for Readers $\ldots \ldots \ldots \ldots \ldots \ldots \ldots \ldots \ldots \ldots \ldots \ldots \ldots \ldots \ldots$

Appendix C: Weekly Gross Alpha and Beta Activities in Air $\ldots \ldots \ldots \ldots \ldots \ldots \ldots \ldots \ldots$

\section{Tables}

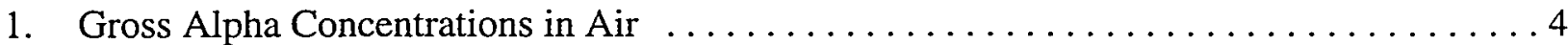

2. Gross Beta Concentrations in Air . .............................. 4

3. Tritium Concentrations in Atmospheric Moisture Samples $\ldots \ldots \ldots \ldots \ldots \ldots \ldots \ldots$

4. Tritium Concentrations in Precipitation Samples at Idaho Falls and EFS $\ldots \ldots \ldots \ldots \ldots 6$

5. Radioactivity in Offsite Water Samples . ......................... 8

6. Radiation Exposures at Distant and Boundary Locations 1998-1999 . . . . . . . . . . . 9

7. Detectable Concentrations of Cesium-137 in Sheep $\ldots \ldots \ldots \ldots \ldots \ldots \ldots \ldots \ldots \ldots$

A-1.Summary of Environmental Surveillance Networks $\ldots \ldots \ldots \ldots \ldots \ldots \ldots \ldots \ldots$

A-2.Approximate Minimum Detectable Concentrations for Radiological Analyses . . . . . . 12

C-1. Weekly Gross Alpha and Beta Concentrations in Air ..................... 15

\section{Figures}

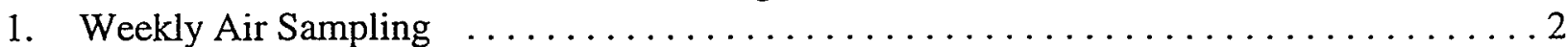

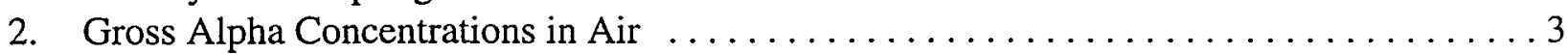

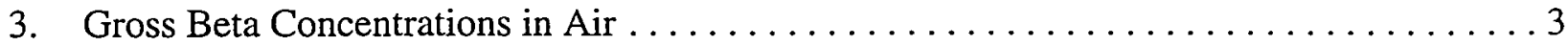

4. Water and Foodstuff Sampling Locations $\ldots \ldots \ldots \ldots \ldots \ldots \ldots \ldots \ldots \ldots$

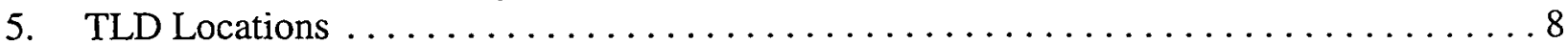




\section{Introduction}

This quarterly report summarizes the data collected by the Environmental Science and Research Foundation's Idaho National Engineering and Environmental Laboratory (INEEL) Offsite Environmental Surveillance Program during the period March 1 to June 30, 1999. Consistent with requirements of applicable Department of Energy (DOE) Orders, the Foundation's environmental surveillance program monitors the effects, if any, of DOE activities on the offsite environment, collects data to verify compliance with applicable environmental laws and regulations, and observes trends in environmental levels of radioactivity. Appendix A summarizes the Foundation's surveillance program. Information useful in understanding this report is given in Appendix B.

Most of the reported environmental concentrations are at or near background levels of radioactivity; many results are near the detection limits of the laboratory procedures. Appendix A summarizes the approximate minimum detectable concentrations of radioactivity which can be detected and quantified for a given sample type and analysis. All results are reported with an associated 2s ("two sigma") uncertainty term. The Foundation uses the following method for interpreting analytical results near the minimum detectable concentration: results less than or equal to the $2 \mathrm{~s}$ uncertainty, which includes some negative values, are considered as "not detected." For results greater than 2s (the 95\% confidence level), but not exceeding 3s (the $99 \%$ confidence interval), detection of the radioactivity is questionable. Results may exceed the $2 \mathrm{~s}$ level simply due to the inherent random nature of radioactive decay events. This is expected to occur approximately $2.5 \%$ of the time. Results exceeding $3 \mathrm{~s}$ are interpreted as indicating the detection of radioactivity.

Where appropriate, measured airborne concentrations of radioactivity in this report are compared to the DOE derived concentration guides. The derived concentration guide is the concentration of a radionuclide which, under conditions of continuous exposure for a year, would result in an effective dose equivalent of 100 millirem (the DOE standard for members of the public). 


\section{Air Sampling}

\subsection{Low-Volume Air Sampling}

Airborne particulate radioactivity was continuously monitored by 17 air samplers (Figure 1), located to provide an effective network to detect INEEL releases of radioactivity. Five offsite air samplers are designated as distant, or background, stations and seven are designated as boundary stations. Three air samplers are situated on the INEEL. Two replicate samplers are also operated for quality control purposes. Onsite locations were used to make comparisons of airborne concentrations of radioactivity with boundary and distant locations. Each air sampler averaged a flow of approximately

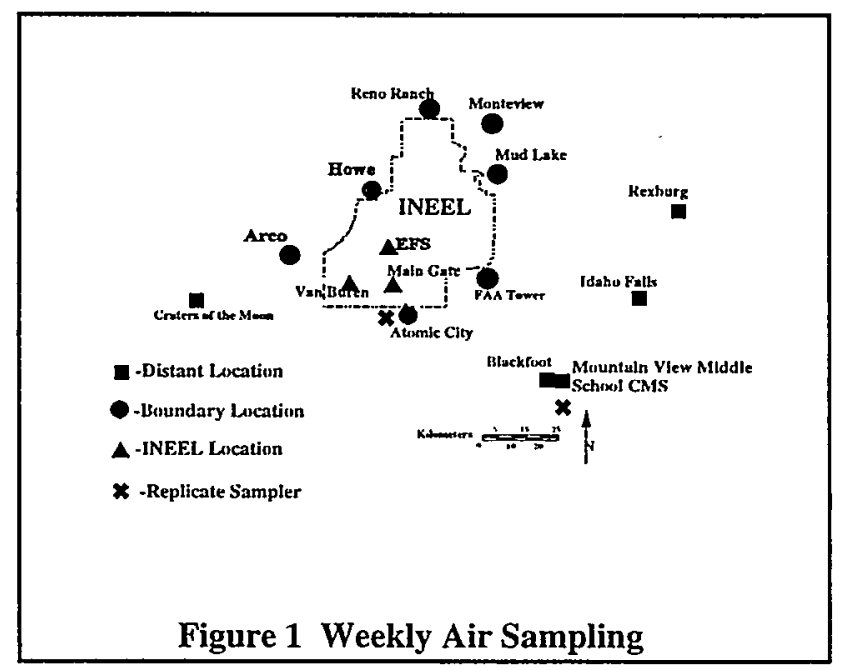
$50 \mathrm{~L} / \mathrm{min}\left(2 \mathrm{ft}^{3} / \mathrm{min}\right)$ through a filter head consisting of two types of filters-a 1.2-micrometer pore size particulate filter and a charcoal cartridge for monitoring radioactive iodine. Filters on each sampler were changed weekly.

Various screening analyses were performed weekly. Charcoal cartridges were screened weekly in batches for ${ }^{131} \mathrm{I}$ activity. If activity was detected in any batch greater than a preset action level, cartridges were then analyzed individually. Particulate filters were counted each week for gross (nonspecific) beta activity in a low-background beta counter after waiting a minimum of four days for the naturallyoccurring progeny of radon and thoron to decay. The particulate filters were also counted for gross alpha activity. At the end of the quarter, weekly filters from each location were combined to form a composite. All composites were then analyzed by gamma spectrometry for specific radionuclides. Selected composites were also analyzed for ${ }^{90} \mathrm{Sr}$ or transuranic radionuclides $\left({ }^{238} \mathrm{Pu},{ }^{239240} \mathrm{Pu}\right.$, and $\left.{ }^{241} \mathrm{Am}\right)$.

No ${ }^{131} \mathrm{I}$ was detected in any of the weekly charcoal cartridges during the second quarter. Figure 2 shows the weekly gross alpha activities measured

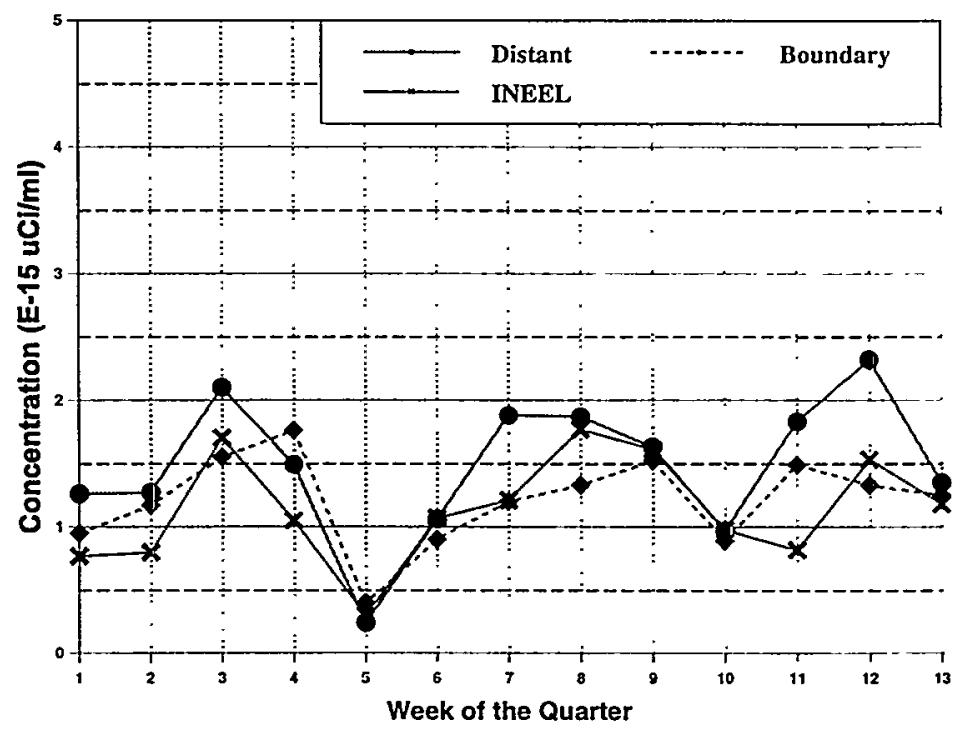

Figure 2 Gross Alpha Activity in Air 
throughout the quarter. All measured gross alpha activities were within the expected range of background levels; activities observed at stations on the INEEL were not significantly different from those at distant and boundary stations. Table 1 summarizes the gross alpha measurements for the quarter.

Figure 3 shows gross beta activities over the 13-week quarter. All measured beta activities were also within the range of expected background values. There were no statistically significant differences between the quarterly mean gross beta activity in samples collected on the INEEL and those at distant or boundary stations. Gamma spectroscopic analyses of air filters detected no human-made radionuclides. Table 2 summarizes the gross beta measurements for the quarter.

Replicate low-volume samplers were operated for quality assurance purposes at Atomic City and at Mountain

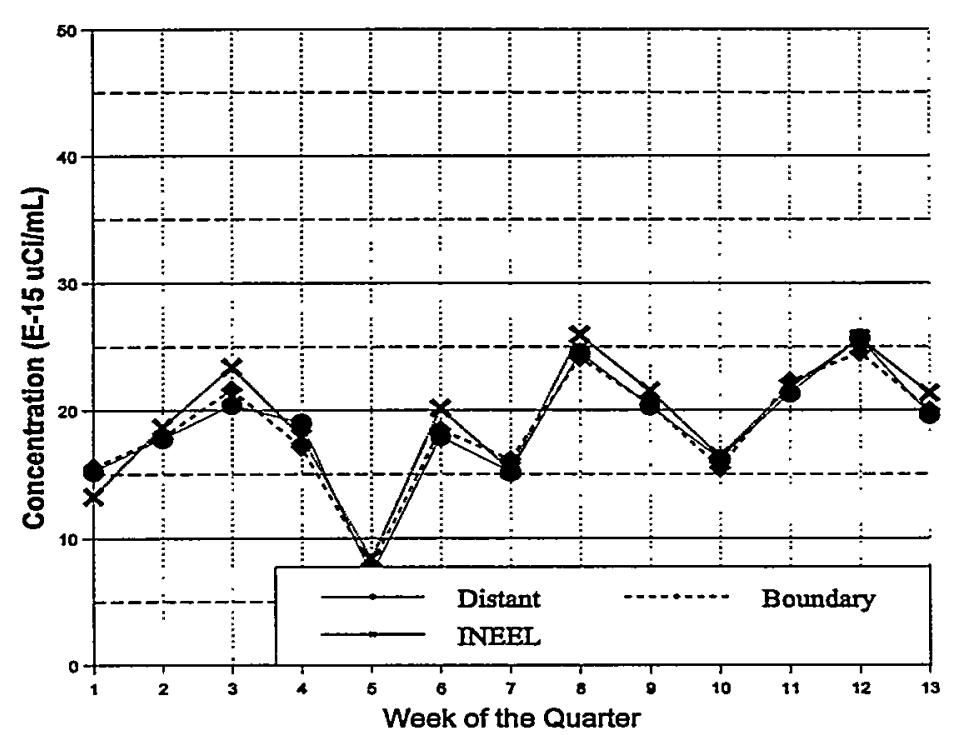

Figure 3 Gross Beta Activity in Air View Middle School in Blackfoot. Paired t-tests were performed to detect differences between the samplers and their corresponding replicates for both gross alpha and gross beta. At the $95 \%$ confidence level, there were no significant differences in replicate measurements of gross alpha or beta activity at either location. Appendix $\mathrm{C}$ contains values of gross alpha and gross beta activities found in weekly air samples for all samplers.

Selected quarterly composite samples were analyzed for transuranics $\left({ }^{241} \mathrm{Am},{ }^{238} \mathrm{Pu}\right.$, and ${ }^{239 / 240} \mathrm{Pu}$ ). None of these radionuclides were detected in any samples. Several composite samples were also selected for ${ }^{90} \mathrm{Sr}$ analysis, and very small concentrations were detected in the composite sample from Monteview $\left(7.4 \pm 4.6 \times 10^{-17} \mu \mathrm{Ci} / \mathrm{ml}\right)$ and from the INEEL Main Gate $(4.5 \pm 3.7 \mathrm{x}$ $10^{-17} \mu \mathrm{Ci} / \mathrm{ml}$ ). Strontium-90 at these concentrations is most likely attributable to resuspended fallout from atmospheric weapons testing (1945 to 1980), although a contribution from INEEL operation cannot be ruled out. These concentrations are well below DOE derived concentration guides and pose no threat to human health.

\section{2 $\mathrm{PM}_{10}$ Air Sampling}

Air sampling for respirable particulates continued at Madison Middle School (Rexburg), Mountain View Middle School (Blackfoot), and Atomic City. $\mathrm{PM}_{10}$ samplers were used to sample airborne particulates with aerodynamic diameters smaller than 10 microns. Particles this size can penetrate the body's natural air filtering system and enter the lungs. These filters are not analyzed for radionuclides. 


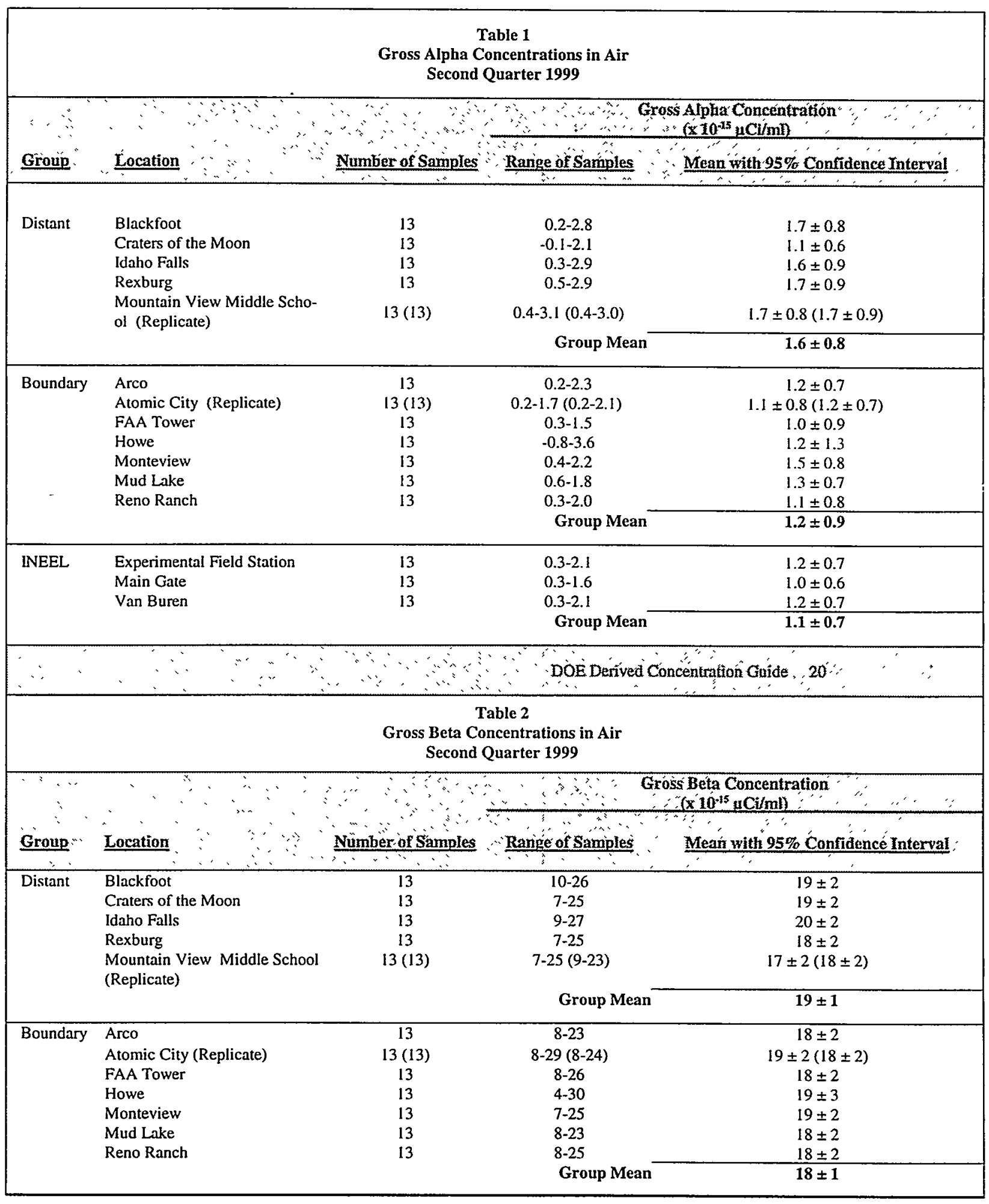




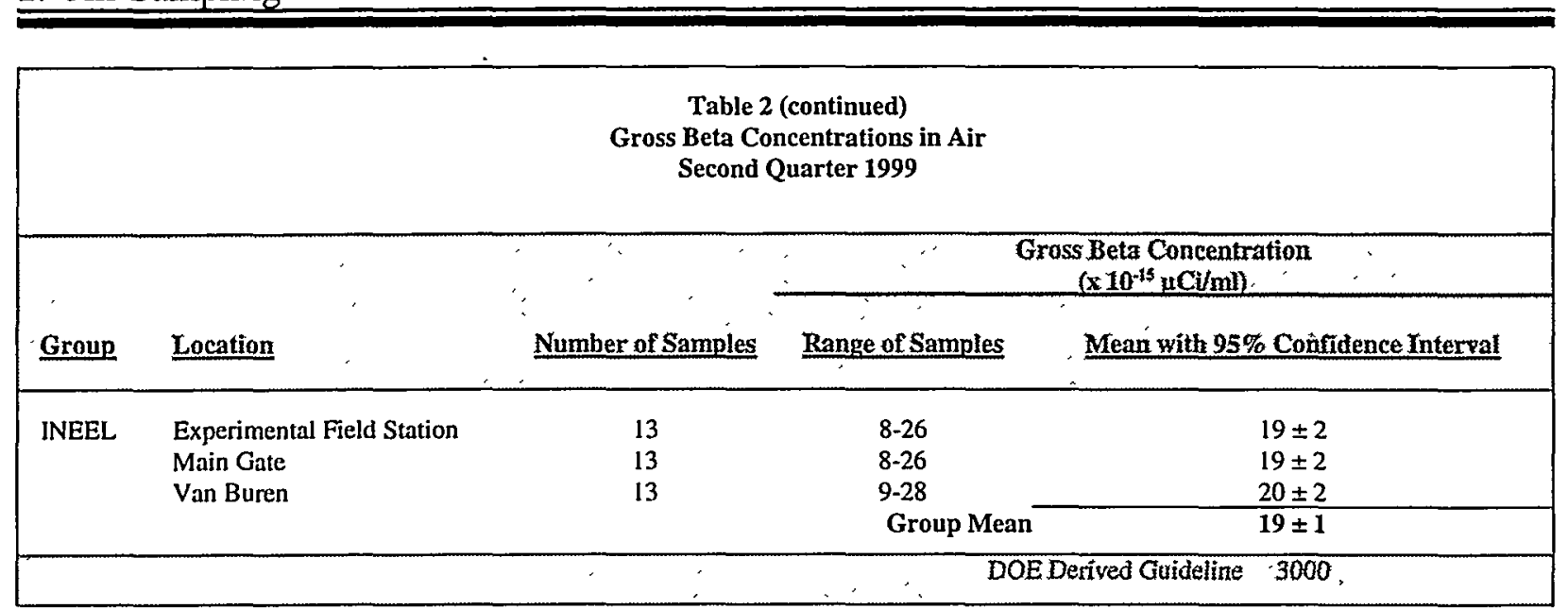

Samples were collected every sixth day from Rexburg, Blackfoot, and Atomic City. Concentrations at Rexburg ranged from 0 to $27 \mu \mathrm{g} / \mathrm{m}^{3}$, with an average of $11 \mu \mathrm{g} / \mathrm{m}^{3}$. At the Blackfoot location, values ranged from 2 to $26 \mu \mathrm{g} / \mathrm{m}^{3}$ with an average concentration of $11 \mu \mathrm{g} / \mathrm{m}^{3}$. In Atomic City the concentrations ranged from 1 to $26 \mu \mathrm{g} / \mathrm{m}^{3}$ with an average concentration of 10 $\mu \mathrm{g} / \mathrm{m}^{3}$. The EPA standard for $\mathrm{PM}_{10}$ is $150 \mu \mathrm{g} / \mathrm{m}^{3}$ averaged over 24 hours, and $50 \mu \mathrm{g} / \mathrm{m}^{3}$ averaged over the entire year.

\subsection{Atmospheric Moisture Sampling}

Four atmospheric moisture samples from Idaho Falls, Rexburg, Blackfoot and Atomic City were obtained during this reporting period. Samples were collected by passing air through a column of silica gel which absorbed water vapor. Tritium concentrations were determined by extracting water from the silica gel and counting the water sample using liquid scintillation. Three of the four samples contained small but detectable concentrations of tritium. Table 3 lists locations and concentrations of the detected tritium. Tritium at these concentrations is probably attributable to natural production by cosmic ray bombardment in the upper atmosphere.

\begin{tabular}{|c|c|c|}
\hline \multicolumn{3}{|c|}{$\begin{array}{c}\text { Table } 3 \\
\text { Tritium Concentrations in Atmospheric Moisture Samples } \\
\text { Second Quarter } 1999\end{array}$} \\
\hline Location & $\begin{array}{l}\text { Tritium Water Concentration } \neq 2 \text { Uncertainty } \\
(\mathrm{pCi} / \mathrm{L})\end{array}$ & $\begin{array}{l}\text { Tritium Air Concentrations } \pm 2 \text { Uncertainty } \\
\qquad\left(10^{-14} \mu \mathrm{Ci} / \mathrm{ml}\right)\end{array}$ \\
\hline Atomic City & $100 \pm 90$ & $4.4 \pm 4.4$ \\
\hline Idaho Falls & $175 \pm 100$ & $6.3 \pm 3.4$ \\
\hline Blackfoot & $120 \pm 90$ & $3.5 \pm 2.9$ \\
\hline
\end{tabular}




\subsection{Precipitation Sampling}

Eleven precipitation samples were collected from Idaho Falls and from onsite locations at the Central Facilities Area (CFA) and the Experimental Field Station (EFS), and analyzed for tritium. Eight of the 11 samples contained small but detectable concentrations of tritium. These values were consistent with concentrations attributed to natural causes. Table 4 shows the date, location, and concentration of the detected tritium. Recounts were performed on the sample collected in Idaho Falls on May 3, the sample collected at CFA on June 1, and the sample collected at EFS on June 8. The Idaho Falls and CFA sample recounts were non-detectable. The recount of the EFS sample was again detectable $(280 \pm 90 \mathrm{pCi} / \mathrm{L})$. The most likely explanation for this value is thought to be laboratory error caused by fluctuating instrument background levels, though a contribution from INEEL cannot be ruled out.

\begin{tabular}{|c|c|c|}
\hline \multicolumn{3}{|c|}{$\begin{array}{c}\text { Table } 4 \\
\text { Tritium Concentrations in Precipitation Samples } \\
\text { Second Quarter 1999 }\end{array}$} \\
\hline Date. & Location & Tritium Concentrations \pm 2 s Uncertainty $(\mathrm{pCin})$ \\
\hline 04/05/99 & Idaho Falls & $130 \pm 100$ \\
\hline $05 / 03 / 99$ & Idaho Falls & $210 \pm 100$ \\
\hline $05 / 04 / 99$ & EFS & $120 \pm 90$ \\
\hline $05 / 18 / 99$ & EFS & $130 \pm 90$ \\
\hline $06 / 01 / 99$ & EFS & $110 \pm 90$ \\
\hline $06 / 01 / 99$ & CFA & $230 \pm 100$ \\
\hline $06 / 02 / 99$ & Idaho Falls & $170 \pm 100$ \\
\hline $06 / 08 / 99$ & EFS & $270 \pm 100$ \\
\hline
\end{tabular}

\section{Milk Sampling}

Milk samples were collected weekly in Idaho Falls and monthly at eight other locations around the INEEL (Figure 4). Two types of locations were sampled: single family dairies and large commercial dairies. Each milk sample was analyzed for ${ }^{131} \mathrm{I}$ by gamma spectrometry. Results were decay-corrected to the time of sample collection. A total of 37 milk samples were collected during the quarter. None of the samples exhibited detectable concentrations of ${ }^{131} \mathrm{I}$.

\section{Water Sampling}

Water samples were collected in May from 14 drinking water locations and four surface water locations in Idaho Falls and the Magic Valley area (Figure 4). Drinking water sampling locations were local businesses. Surface water locations were the Snake River in Bliss and Idaho Falls and springs in the Thousand Springs area and in Idaho Falls. These springs are some of the 
outlets for the Snake River Plain

Aquifer, which flows beneath the

INEEL. Samples were analyzed for gross alpha and gross beta activity by residue counting techniques and were analyzed for tritium by liquid scintillation. Three surface samples (from Alpheus Springs near Twin Falls, from the Snake River at Idaho Falls, and from the Snake River near Bliss) contained detectable tritium concentrations. Recounts were performed on the samples from the Snake River at Alpheus Springs and Idaho Falls;

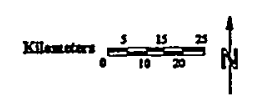
these recounts were non-detectable for tritium. Drinking water samples from Arco and from Monteview

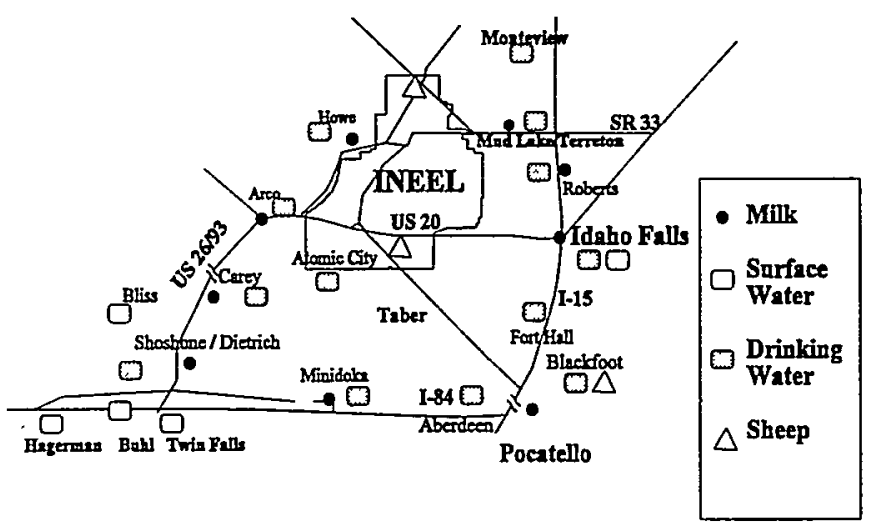

Figure 4 Water and Foodstuff Sampling Locations contained barely detectable gross alpha activities. Most of the samples contained detectable gross beta activity. Table 5 summarizes these findings. At these levels, alpha and beta radioactivity in water samples is generally attributed to decay products of naturally-occurring radionuclides, sorbed by water as it flows through the earth's crust. The observed tritium concentrations are consistent with natural production of tritium in the upper atmosphere by cosmic ray bombardment. None of the detected radioactivity approached applicable DOE derived concentration guides, and none of these concentrations constituted any threat to human health. 
3. Milk Sampling

Table 5

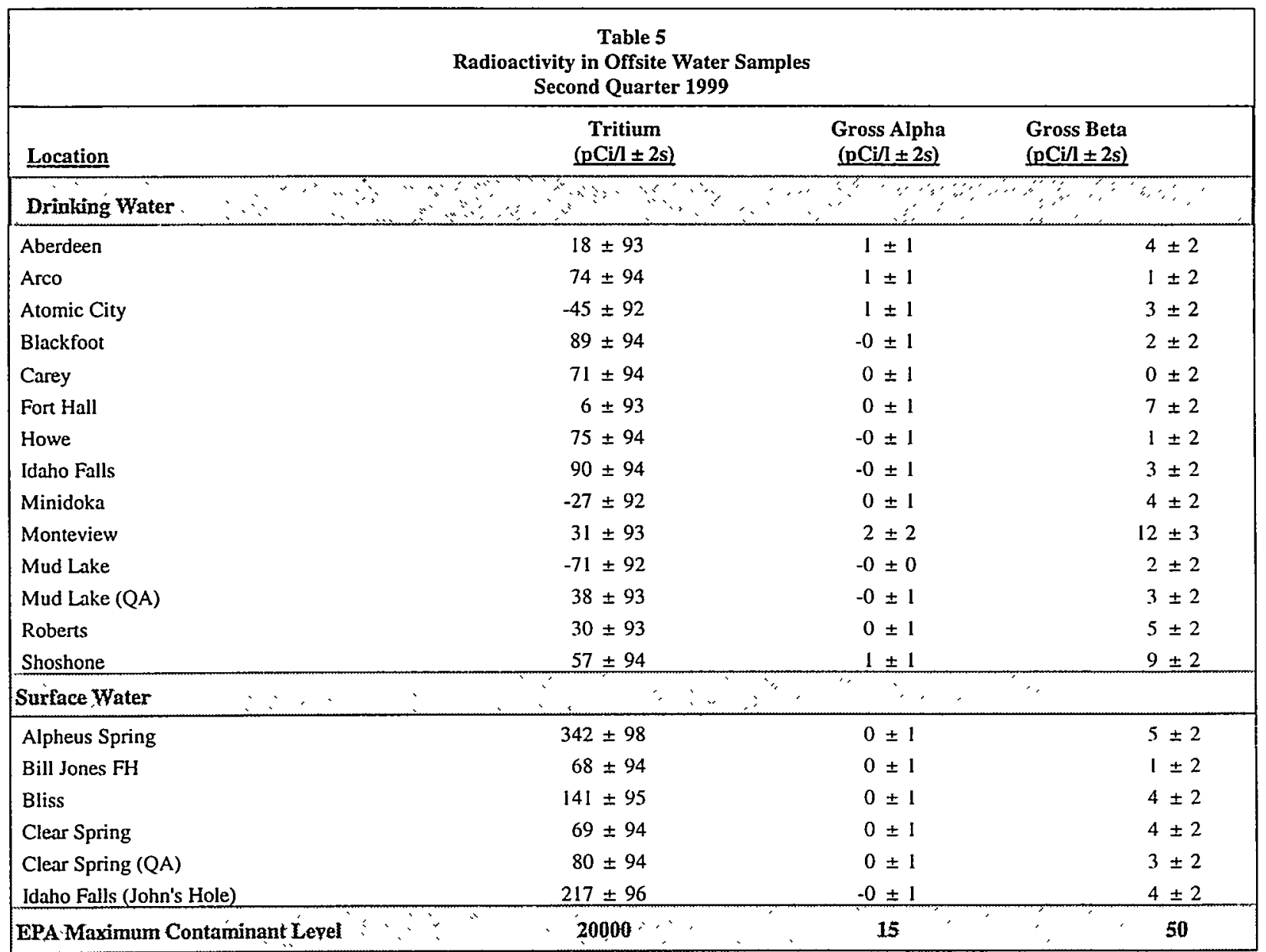

\section{Environmental Radiation}

Thermoluminescent dosimeters (TLDs), changed semiannually, were collected from six boundary and eight distant locations (Figure 5). The results for the first half of 1999 (November 1998-May 1999) show exposure levels similar to those of the previous six-month interval (Table 6). There were no statistically significant differences between the distant and boundary groups.

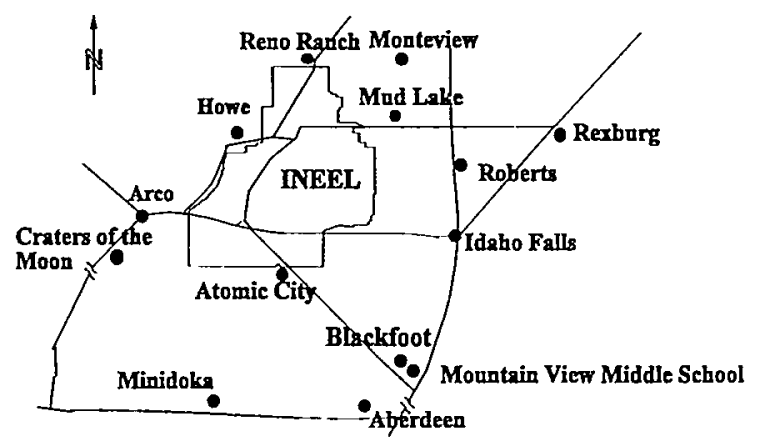

Figure 5 TLD Locations

8 
Table 6

Radiation Exposures at Distant and Boundary Locations (1998-1999)

\begin{tabular}{|c|c|c|c|}
\hline Location & . & Exposure $(m R \pm 2 s)$ & , \\
\hline & $\begin{array}{l}\text { May 1998- } \\
\text { Oct. } 1998\end{array}$ & $\begin{array}{l}\text { Nov. 1998:- } \\
\text { May } 1999\end{array}$ & Annual Total $\pm 2 s$ \\
\hline r & \multicolumn{2}{|c|}{ Distant Locations. } & $\because$ \\
\hline Aberdeen & $66 \pm 3$ & $65 \pm 5$ & $131 \pm 6$ \\
\hline Blackfoot & $65 \pm 4$ & $56 \pm 3$ & $121 \pm 5$ \\
\hline Craters of the Moon & $66 \pm 5$ & $55 \pm 3$ & $121 \pm 6$ \\
\hline Idaho Falls & $60 \pm 4$ & $65 \pm 9$ & $125 \pm 7$ \\
\hline Minidoka & $59 \pm 5$ & $58 \pm 3$ & $117 \pm 6$ \\
\hline Rexburg & $73 \pm 3$ & $70 \pm 5$ & $143 \pm 6$ \\
\hline Roberts & $69 \pm 4$ & $64 \pm 3$ & $133 \pm 5$ \\
\hline Mountain View Middle School & $57 \pm 4$ & $56 \pm 6$ & $113 \pm 7$ \\
\hline Group Mean & $64 \pm 4$ & $61 \pm 4$ & $126 \pm 6$ \\
\hline . & \multicolumn{2}{|c|}{ Bóundary Locations } & v \\
\hline Arco & $63 \pm 3$ & $63 \pm 8$ & $126 \pm 9$ \\
\hline Atomic City & $66 \pm 4$ & $60 \pm 5$ & $126 \pm 6$ \\
\hline Howe & $63 \pm 5$ & $62 \pm 5$ & $125 \pm 7$ \\
\hline Monteview & $63 \pm 3$ & $57 \pm 4$ & $120 \pm 5$ \\
\hline Mud Lake & $68 \pm 3$ & $59 \pm 2$ & $127 \pm 4$ \\
\hline Reno Ranch & $56 \pm 5$ & $53 \pm 6$ & $109 \pm 8$ \\
\hline Group Mean & $63 \pm 4$ & $59 \pm 5$ & $122 \pm 6$ \\
\hline
\end{tabular}

\section{Livestock and Game Animal Sampling}

During May, the Foundation sampled four sheep which had grazed on the INEEL. Two sheep from Blackfoot which had never grazed on the INEEL were used as controls against which to compare values of any radionuclides detected in the on-site sheep. Sampling locations are indicated in Figure 4.

Three of the four sheep which had grazed on the INEEL exhibited detectable concentrations of cesium-137 in muscle tissue. Muscle tissue samples from both control sheep also contained detectable cesium-137. The cesium-137 concentrations of in muscle samples from the on-site sheep were not significantly greater than those from the control sheep. Liver samples from three of the on-site sheep and from one of the control sheep contained detectable concentrations of cesium-137. Concentrations in on-site sheep liver samples were not significantly greater than those of the control sheep. The analytical results for sheep with detectable concentrations can be seen in Table 7. Since the control sheep contained levels of cesium-137 similar to those in test 
sheep, these detections can be attributed to residual fallout from historic above-ground weapons testing. These levels are insignificant and pose no potential health problems to humans.

Muscle, liver, and thyroid samples were collected from an elk which had been accidentally killed on INEEL roads in June. No radionuclides were detected in the elk.

\begin{tabular}{|l|c|}
\hline & $\begin{array}{c}\text { Table } 7 \\
\text { Detectable Concentrations of Cesium-137 in Sheep } \\
\text { Second Quarter 1999 }\end{array}$ \\
\hline Sheep Number \& Tissue Type. & $6.1 \pm 2.4$ \\
1 Muscle & $3.7 \pm 2.2$ \\
1 Liver & $5.6 \pm 3.0$ \\
2 Muscle & $4.8 \pm 2.4$ \\
2 Liver & $6.0 \pm 2.7$ \\
3 Muscle & $7.0 \pm 3.0$ \\
3 Liver & \\
Control I Muscle & $3.8 \pm 2.6$ \\
Control 2 Muscle & $3.5 \pm 2.5$ \\
Control 2 Liver & $2.6 \pm 2.1$ \\
\hline
\end{tabular}




\section{Appendix A Summary of}

\section{Environmental Surveillance Networks}

\begin{tabular}{|c|c|c|c|c|}
\hline \multicolumn{5}{|c|}{$\begin{array}{l}\text { Table A-1 } \\
\text { Summary of the Foundation's Environmental Surveillance Program }\end{array}$} \\
\hline \multirow{2}{*}{$\begin{array}{l}\text { Sample Type } \\
\text { Analysis }\end{array}$} & \multirow{2}{*}{$\begin{array}{l}\text { Collection } \\
\text { Frequency }\end{array}$} & \multicolumn{3}{|c|}{ Locations } \\
\hline & & Distant & Boundary & INEEL \\
\hline Air & & & & \\
\hline Gross Alpha & weekly & $\begin{array}{l}\text { Blackfoot, Craters of the Moon, ldaho } \\
\text { Falls, Rexburg }\end{array}$ & $\begin{array}{l}\text { Arco, Atomic City, FAA Tower, Howe, } \\
\text { Monteview, Mud Lake, Reno Ranch }\end{array}$ & $\begin{array}{l}\text { Main Gate, EFS, Van } \\
\text { Buren }\end{array}$ \\
\hline $\begin{array}{r}\text { Gross Beta1 } \\
\text { |3!I }\end{array}$ & weekly & $\begin{array}{l}\text { Blackfoot, Craters of the Moon, Idaho } \\
\text { Falls, Rexburg }\end{array}$ & $\begin{array}{l}\text { Arco, Atomic City, FAA Tower, Howe, } \\
\text { Monteview, Mud Lake, Reno Ranch }\end{array}$ & $\begin{array}{l}\text { Main Gate, EFS, Van } \\
\text { Buren }\end{array}$ \\
\hline $\begin{array}{r}\text { Gammi Spec } \\
\text { Particulate Mass }\end{array}$ & quarterly & $\begin{array}{l}\text { Blackfoot, Craters of the Moon, Idaho } \\
\text { Falls, Rexburg }\end{array}$ & $\begin{array}{l}\text { Arco, Atomic City, FAA Tower, Howe, } \\
\text { Monteview, Mud Lake, Reno Ranch }\end{array}$ & $\begin{array}{l}\text { Main Gate, EFS, Van } \\
\text { Buren }\end{array}$ \\
\hline $\begin{array}{r}{ }^{25} \mathrm{Sr} \\
\text { Transuranics }\end{array}$ & quarterly & Rotating schedule & Rotating schedule & Rotating schedule \\
\hline PM-10 & every sixth day & Rexburg, Blackfoot & Atomic City & None \\
\hline \multicolumn{5}{|l|}{ Air Moisture } \\
\hline Tritium & 4 to 13 weeks & Idaho Falls & Atomic City & None \\
\hline \multicolumn{5}{|l|}{ Precipitation } \\
\hline Tritium & monthly & Idaho Falls & None & CFA \\
\hline Tritium & weekly & None & None & EFS \\
\hline \multicolumn{5}{|l|}{ Surface $\mathrm{H}, \mathrm{O}$} \\
\hline $\begin{array}{l}\text { Gross Alpha, } \\
\text { Gross Beta, }{ }^{3} \mathrm{H}\end{array}$ & semiannually & $\begin{array}{l}\text { Twin Falls, Buhl, Hagerman } \\
\text { Idaho Falls, Bliss }\end{array}$ & None & None \\
\hline \multicolumn{5}{|l|}{ Drinking $\mathrm{H}_{2} \mathrm{O}$} \\
\hline $\begin{array}{r}\text { Gross Alphil } \\
\text { Gross Betu, }{ }^{1} \mathrm{H}\end{array}$ & semiannually & $\begin{array}{l}\text { Aberdeen, Blackfoot, Carey, Idaho Falls, } \\
\text { Fort Hall, Minidoka, Roberts, Shoshone }\end{array}$ & $\begin{array}{l}\text { Arco, Atomic City, Howe, Monteview, } \\
\text { Mud Lake }\end{array}$ & None \\
\hline \multicolumn{5}{|l|}{ Milk } \\
\hline 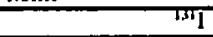 & weekly & Idaho Falls & None & None \\
\hline 13.1I & monthly & $\begin{array}{l}\text { Blackfoot, Carey, Dietrich, Minidoka, } \\
\text { Roberts }\end{array}$ & Howe, Terreton, Arco & None \\
\hline $\begin{array}{l}\text { Tritium } \\
{ }^{90} \mathrm{Sr}\end{array}$ & annually & $\begin{array}{l}\text { Blackfoot, Carey, Dietrich, Idaho Falls, } \\
\text { Minidoka, Roberts }\end{array}$ & Howe, Terreton, Arco & None \\
\hline \multicolumn{5}{|l|}{ Potatoes } \\
\hline $\begin{array}{l}\text { Gamma Spec } \\
{ }^{\infty} \mathrm{Sr}\end{array}$ & annually & Blackfoot, Idaho Falls, Rupert & Arco, Mud Lake & None \\
\hline \multicolumn{5}{|l|}{ Wheat } \\
\hline $\begin{array}{r}\text { Gummia Spec } \\
{ }_{\mathrm{y}}^{\mathrm{Ser}} \mathrm{Sr}\end{array}$ & annually & $\begin{array}{l}\text { American Falls, Blackfooh, Diecrich, } \\
\text { Idaho Falls, Minidoka, Carey }\end{array}$ & $\begin{array}{l}\text { Arco, Monteview, Mud Lake, Tabor, } \\
\text { Terreton }\end{array}$ & None \\
\hline \multicolumn{5}{|l|}{ Lettuce } \\
\hline Gamma Spec & annually & Blackfoot, Carey, Idaho Falls, Pocatello & Arco, Atomic City, Howe, Mud Lake & None \\
\hline \multicolumn{5}{|l|}{ Fish of } \\
\hline Gummi Spec & annually & None & None & Big Lost River \\
\hline \multicolumn{5}{|l|}{ Sheep } \\
\hline Gamma Spec & annually & Blackfoot & None & INEEL grazing areas \\
\hline \multicolumn{5}{|l|}{ Waterfowl } \\
\hline $\begin{array}{l}\text { Gamma Spec } \\
\text { "Sr Transuranics }\end{array}$ & annually & Fort Hall & None & Waste disposal ponds \\
\hline \multicolumn{5}{|l|}{ Game } \\
\hline Gamma Spec & varies & None & None & INEEL roads \\
\hline \multicolumn{5}{|l|}{ Soll } \\
\hline $\begin{array}{l}\text { Gamma Spec } \\
{ }_{\text {"S }} \mathrm{r} \\
\text { Transuranics }\end{array}$ & biennially & $\begin{array}{l}\text { Carey, Crystal Ice Caves, Blackfoot, St. } \\
\text { Anthony }\end{array}$ & $\begin{array}{l}\text { Butte City, Monteview, Atomic City, FAA } \\
\text { Tower, Howe, Mud Lake (2), Reno Ranch }\end{array}$ & None \\
\hline \multicolumn{5}{|l|}{ TLDs } \\
\hline Gamma Radiation & semiannual & $\begin{array}{l}\text { Aberdeen, Blackfoot, Craters of the } \\
\text { Moon, Idaho Falls, Minidoka, Rexburg, } \\
\text { Roberts }\end{array}$ & $\begin{array}{l}\text { Arco, Atomic City, Howe, Monteview, } \\
\text { Mud Lake, Reno Ranch }\end{array}$ & None \\
\hline
\end{tabular}




\begin{tabular}{|c|c|c|c|c|}
\hline \multicolumn{5}{|c|}{$\begin{array}{c}\text { Table A-2 } \\
\text { Summary of Approximate Minimum Detectable Concentrations for Radiological Analyses }\end{array}$} \\
\hline Sample Type & Analysis & $\begin{array}{c}\text { Approximate Minimum } \\
\begin{array}{c}\text { Detectable } \\
\text { Concentration }\end{array} \\
\frac{\text { (MDC) }}{\text { (MDC }}\end{array}$ & 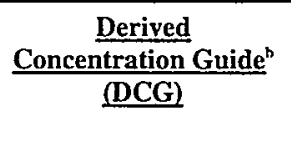 & $\begin{array}{l}\text { Drinking Water } \\
\text { Detection Limits }^{c}\end{array}$ \\
\hline \multirow[t]{7}{*}{ Air (particulate filter) } & Gross alpha & $1 \times 10^{-15} \mu \mathrm{Ci} / \mathrm{ml}$ & $2 \times 10^{-14} \mu \mathrm{Ci} / \mathrm{ml}$ & -- \\
\hline & Gross beta & $3 \times 10^{-15} \mu \mathrm{Ci} / \mathrm{ml}$ & $3 \times 10^{-12} \mu \mathrm{Ci} / \mathrm{ml}$ & -- \\
\hline & $\begin{array}{l}\text { Specific gamma } \\
\left({ }^{177} \mathrm{Cs}\right)\end{array}$ & $3 \times 10^{-16} \mu \mathrm{Ci} / \mathrm{ml}$ & $4 \times 10^{-10} \mu \mathrm{Ci} / \mathrm{mI}$ & \\
\hline & ${ }^{237} \mathrm{Pu}$ & $2 \times 10^{-18} \mu \mathrm{Ci} / \mathrm{ml}$ & $3 \times 10^{-14} \mu \mathrm{Ci} / \mathrm{ml}$ & \\
\hline & ${ }^{2399240} \mathrm{Pu}$ & $3 \times 10^{-18} \mu \mathrm{Ci} / \mathrm{ml}$ & $2 \times 10^{-14} \mu \mathrm{Ci} / \mathrm{ml}$ & \\
\hline & ${ }^{2 s 1} \mathrm{Am}$ & $2 \times 10^{-18} \mu \mathrm{Ci} / \mathrm{ml}$ & $2 \times 10^{-14} \mu \mathrm{Ci} / \mathrm{ml}$ & -- \\
\hline & ${ }^{401} \mathrm{Sr}$ & $3 \times 10^{.17} \mu \mathrm{Ci} / \mathrm{ml}$ & $9 \times 10^{-12} \mu \mathrm{Ci} / \mathrm{ml}$ & .. \\
\hline Air (charcoal cartridge) ${ }^{d}$ & 131 & $4 \times 10^{-15} \mu \mathrm{Ci} / \mathrm{ml}$ & $4 \times 10^{-119} \mu \mathrm{Ci} / \mathrm{ml}$ & -- \\
\hline Air (atmospheric moisture) & ${ }^{3} \mathrm{H}$ & $4 \times 10^{-12} \mu \mathrm{Ci} / \mathrm{ml}$ & $\mathrm{I} \times 10^{-7} \mu \mathrm{Ci} / \mathrm{ml}$ & -- \\
\hline Air (precipitation) & ${ }^{3} \mathrm{H}$ & $1 \times 10^{-7} \mu \mathrm{Ci} / \mathrm{ml}$ & $2 \times 10^{-3} \mu \mathrm{Ci} / \mathrm{ml}$ & -- \\
\hline \multirow[t]{3}{*}{ Water (drinking \& surface) } & Gross alpha & $3 \mathrm{pCi} / 1$ & $30 \mathrm{pCi} / \mathrm{l}$ & $3 \mathrm{pCi} / \mathrm{l}$ \\
\hline & Gross beta & $2 \mathrm{pCi} / \mathrm{l}$ & $100 \mathrm{pCi} / \mathrm{l}$ & $4 \mathrm{pCi} / \mathrm{l}$ \\
\hline & ${ }^{3} \mathrm{H}$ & $100 \mathrm{pCi} / 1$ & $2 \times 10^{6} \mathrm{pCi} / 1$ & $1000 \mathrm{pCi} / 1$ \\
\hline Milk & ${ }^{131} I$ & $3 \times 10^{-9} \mu \mathrm{Ci} / \mathrm{ml}$ & - & $\cdots$ \\
\hline \multirow[t]{2}{*}{ Wheat } & $\begin{array}{l}\text { Specific gamma } \\
\left({ }^{137} \mathrm{Cs}\right)\end{array}$ & $4 \times 10^{-9} \mu \mathrm{Ci} / \mathrm{g}$ & - & .. \\
\hline & ${ }^{91} \mathrm{Sr}$ & $5 \times 10^{-4} \mu \mathrm{Ci} / g$ & -- & -- \\
\hline \multirow[t]{2}{*}{ Lettuce } & $\begin{array}{l}\text { Specific gamma } \\
\left({ }^{137} \mathrm{Cs}\right)\end{array}$ & $1 \times 10^{-7} \mu \mathrm{Ci} / \mathrm{g}$ & -- & -- \\
\hline & "Sr $\mathrm{r}$ & $2 \times 10^{-7} \mu \mathrm{Ci} / \mathrm{g}$ & -- & - \\
\hline \multicolumn{5}{|c|}{$\begin{array}{l}\text { a. The MDC is an estimate of the concentration of radioactivity in a given sample type that can be identified with a } 95 \% \text { level of confidence and a precision of plus } \\
\text { or minus } 100 \% \text { under a specified set of typical laboratory measurement conditions. } \\
\text { b. DCGs, set by the DOE, represent reference values for radiation exposure. They are based on a radiation dose of } 100 \mathrm{mrem} / \mathrm{yr} \text { for exposure through a particular } \\
\text { exposure mode such as direct exposure. inhalation, or ingestion of water. } \\
\text { c. These limits are required by the National Primary Drinking Water Regulations ( } 40 \mathrm{CFR} 14 \mathrm{I} \text { ). The "detection limit" is the terminology used by the EPA and } \\
\text { means the same as the MDC defined above. } \\
\text { d. The approximate MDC is based on an average filtered air volume (pressure corrected) of } 570 \mathrm{~m}^{3} / \text { week. } \\
\text { e. The approximate MDC is expressed for tricium (as tritiated water) in air, and is based on an average filtered air volume of } 25 \mathrm{~m}^{3} \text {, assuming an average sampling } \\
\text { period of eight weeks. }\end{array}$} \\
\hline
\end{tabular}




\section{Appendix B \\ Helpful Information for Readers}

\section{Radionuclide Nomenclature}

Radionuclides are sometimes expressed with the one- or two-letter chemical symbol for the element. A radionuclide is an unstable, or radioactive, form of an element. A given element may have many different radionuclides. Each is designated by a superscript number to the left of the chemical symbol. This number is the atomic weight of the radionuclide, equal to the number of protons and neutrons in its nucleus. Radionuclides which may be used in this report are shown in the following table:

\begin{tabular}{|c|c|c|c|}
\hline Symbol & $\underline{\text { Radionuclide }}$ & Symbol & $\underline{\text { Radionuclide }}$ \\
\hline${ }^{3} \mathrm{H}$ & Tritium & ${ }^{131} \mathrm{I}$ & Iodine-131 \\
\hline${ }^{7} \mathrm{Be}$ & Beryllium-7 & ${ }^{1.4} \mathrm{Cs}$ & Cesium-134 \\
\hline${ }^{2} \mathrm{Cr}$ & - Chromium-51 & ${ }^{137} \mathrm{Cs}$ & Cesium- 137 \\
\hline${ }^{4} \mathrm{Mn}$ & Manganese-54 & ${ }^{144} \mathrm{Ce}$ & Cerium- 144 \\
\hline${ }^{48} \mathrm{Co}$ & Cobalt-58 & ${ }^{181} \mathrm{Hf}$ & Hafnium-181 \\
\hline${ }^{(2)} \mathrm{Co}$ & Cobalt -60 & ${ }^{238} \mathrm{Pu}$ & Plutonium-238 \\
\hline${ }^{n} \mathrm{Zn}$ & Zinc- 65 & ${ }^{239 / 240} \mathrm{Pu}$ & Plutonium-239/240 \\
\hline${ }^{* 1} \mathrm{Sr}$ & Strontium-90 & ${ }^{241} \mathrm{Am}$ & Americium-241 \\
\hline${ }^{95} \mathrm{Nb}$ & Niobium-95 & & \\
\hline
\end{tabular}

\section{Scientific Notation}

Scientific notation is used to express numbers which are very small and very large. A very small number will be expressed with a negative exponent, e.g., $1.3 \times 10^{-6}$. To convert this number to the more commonly used form, the decimal point must be moved left by the number of places equal to the exponent (in this case, six). The number thus becomes 0.0000013 .

For large numbers, those with a positive exponent, the decimal point is moved to the right by the number of places equal to the exponent. The number $1,000,000$ (or one million) can be written as $1.0 \mathrm{x}$ $10^{6}$.

\section{Unit Prefixes}

Units for very small and very large numbers are commonly expressed with a prefix. One example is the prefix kilo, abbreviated $\mathrm{k}$, which means 1,000 of a given unit. A kilometer is therefore equal to 1,000 meters. Prefixes that may be used in this report are:

$\begin{array}{ccc}\text { Prefix } & \text { Abbreviation } & \text { Meaning } \\ \text { milli } & \mathrm{m} & 1 / 1,000\left(=1 \times 10^{-3}\right) \\ \text { micro } & \mu & 1 / 1,000,000\left(=1 \times 10^{-6}\right) \\ \text { pico } & \mathrm{p} & 1 / 1,000,000,000,000\left(=1 \times 10^{-12}\right)\end{array}$

\section{Units of Radioactivity and Radiation Exposure and Dose}

The basic unit of radioactivity used in this report is the curie, abbreviated $\mathrm{Ci}$. The curie is defined as the amount of radioactivity equivalent to 37 billion nuclear transformations per second. Historically, this was based upon the radioactivity from one gram of the radionuclide Radium-226. For any other radionuclide, one curie is the amount of that radionuclide that decays at this same rate. 
Radiation exposure is expressed in terms of the Roentgen ( $R$ ), the amount of ionization produced by gamma radiation in air. Dose is given in units of "Roentgen equivalent man," or "rem," which takes into account the effect of radiation on tissues. For the types of environmental radiation generally encountered, the unit of Roentgen is approximately numerically equal to the unit of rem.

\section{Units of Environmental Concentrations}

Concentration of radioactivity in air and milk samples are expressed in units of microcuries per milliliter $(\mu \mathrm{Ci} / \mathrm{ml})$. Concentrations in water samples are expressed as picocuries per liter $(\mathrm{pCi} / \mathrm{l})$; federal standards are expressed in these units. Radioactivity in foodstuffs are given in microcuries per gram $(\mu \mathrm{Ci} / \mathrm{g})$, dry weight. Radioactivity in soil samples is expressed as picocuries per gram (pCi/g), dry weight. Annual human radiation exposure, measured by environmental dosimeters, is expressed in units of milliRoentgens ( $\mathrm{mR})$. This is sometimes expressed in terms of dose as millirem (mrem).

\section{Uncertainty of Measurements}

Due to many variables, there is always an uncertainty associated with the measurement of environmental contaminants. For radioactivity, the predominant source of uncertainty is due to the inherent statistical nature of radioactive decay events, particularly at the low activity levels encountered in environmental samples. The uncertainty of a measurement is denoted by following the result with a " \pm " (uncertainty) term. This report follows convention in reporting the uncertainty as a $95 \%$ confidence limit (or interval), designated in the tables as " $\pm 2 \mathrm{~s}$." That means there is approximately a $95 \%$ level of confidence that the real concentration in the sample lies somewhere between the measured (reported) concentration minus the uncertainty term and the measured (reported) concentration plus the uncertainty term.

\section{Negative Numbers as Results}

Environmental measurements are frequently conducted at levels where the contaminant, such as radioactivity, cannot be distinguished from natural background levels. In this case, the result will still be reported by the analytical laboratory, even though it is below the measurement system's approximate minimum detectable concentration, or is less than zero. Negative values occur when the measured result is less than a pre-established average background level for the particular system and procedure used. These values, rather than "not detectable" or "zero," are reported to better enable statistical analyses and to observe trends in the data.

\section{Gross versus Specific Analyses}

Many of the radiological analyses of environmental samples yield information only about the overall, or gross, amount of a particular type of radiation (e.g., gross beta), rather than identifying and quantifying specific radionuclides. For example, rather than performing an analysis for particular gamma-emitting radionuclides, called gamma spectroscopy, one can do a gross gamma or, more commonly, a gross beta analysis, since gamma-emitting radionuclides also emit beta particles. This type of analysis is an effective screening tool and is much quicker and less costly than specific radionuclide analyses. 


\section{Appendix C \\ Weekly Gross Alpha and Gross Beta Concentrations in Air 2nd Quarter 1999}

\section{Location Collection Date}

$\begin{array}{ll}\text { Blackfoot } & 04 / 07 / 99 \\ \text { NOAA } & 04 / 14 / 99 \\ & 04 / 21 / 99 \\ & 04 / 28 / 99 \\ & 05 / 05 / 99 \\ 05 / 12 / 99 \\ 05 / 19 / 99 \\ 05 / 26 / 99 \\ 06 / 02 / 99 \\ 06 / 09 / 99 \\ 06 / 16 / 99 \\ 06 / 23 / 99 \\ 06 / 30 / 99\end{array}$

$\begin{array}{cc}\text { Craters of } & 04 / 07 / 99 \\ \text { the Moon } & 04 / 14 / 99 \\ & 04 / 21 / 99 \\ & 04 / 28 / 99 \\ & 05 / 05 / 99 \\ & 05 / 12 / 99 \\ 05 / 19 / 99 \\ 05 / 26 / 99 \\ 06 / 02 / 99 \\ 06 / 09 / 99 \\ 06 / 16 / 99 \\ 06 / 23 / 99 \\ 06 / 30 / 99\end{array}$

Idaho Falls $04 / 07 / 99$

$04 / 14 / 99$

$04 / 21 / 99$

$04 / 28 / 99$

$05 / 05 / 99$

$05 / 12 / 99$

$05 / 19 / 99$

$05 / 26 / 99$

$06 / 02 / 99$
Gross Alpha Concentration $\pm 2 \mathrm{~s}$

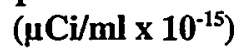

Gross Beta Concentration $\pm 2 \mathrm{~s}$ $\left(\mu \mathrm{Ci} / \mathrm{ml} \mathbf{1 0}^{-15}\right)$

$$
\begin{aligned}
& 1.5 \pm 0.6 \\
& 1.7 \pm 0.6 \\
& 2.8 \pm 0.9 \\
& 1.4 \pm 0.5 \\
& 0.2 \pm 0.3 \\
& 0.8 \pm 0.5 \\
& 1.9 \pm 0.9 \\
& 2.6 \pm 1.0 \\
& 1.6 \pm 0.9 \\
& 1.6 \pm 0.8 \\
& 2.4 \pm 1.1 \\
& 1.8 \pm 0.9 \\
& 1.9 \pm 0.7
\end{aligned}
$$

$0.7 \pm 0.4$

$0.9 \pm 0.4$

$1.5 \pm 0.8$

$1.5 \pm 0.5$

$-0.1 \pm 0.2$

$0.9 \pm 0.5$

$1.1 \pm 0.7$

$1.1 \pm 0.8$

$1.5 \pm 0.8$

$0.9 \pm 0.7$

$2.1 \pm 0.8$

$1.2 \pm 0.8$

$0.7 \pm 0.4$

$1.4 \pm 0.6$

$0.9 \pm 0.6$

$1.8 \pm 1.1$

$1.3 \pm 0.6$

$0.3 \pm 0.4$

$1.4 \pm 0.7$

$2.3 \pm 1.2$

$2.0 \pm 1.2$

$1.4 \pm 1.1$
$17 \pm 2$

$18 \pm 2$

$25 \pm 2$

$15 \pm 2$

$9 \pm 1$

$20 \pm 2$

$18 \pm 2$

$26 \pm 2$

$21 \pm 2$

$15 \pm 2$

$23 \pm 2$

$24 \pm 2$

$20 \pm 2$

$18 \pm 1$

$18 \pm 1$

$21 \pm 2$

$20 \pm 1$

$7 \pm 1$

$19 \pm 2$

$14 \pm 1$

$24 \pm 2$

$22 \pm 2$

$16 \pm 2$

$21 \pm 2$

$25 \pm 2$

$20 \pm 2$

$15 \pm 2$

$20 \pm 2$

$21 \pm 2$

$19 \pm 2$

$9 \pm 2$

$21 \pm 2$

$17 \pm 2$

$25 \pm 3$

$22 \pm 2$ 


\section{Appendix C}

\section{Weekly Gross Alpha and Gross Beta Concentrations in Air 2nd Quarter 1999}

Location Collection Date

$\begin{array}{ccc} & 06 / 09 / 99 & 1.0 \pm 1.0 \\ 06 / 16 / 99 & 2.1 \pm 1.3 \\ 06 / 23 / 99 & 2.9 \pm 1.3 \\ & 06 / 30 / 99 & 1.5 \pm 0.8 \\ \text { Rexburg } & 04 / 07 / 99 & 0.9 \pm 0.4 \\ & 04 / 14 / 99 & 1.1 \pm 0.5 \\ 04 / 21 / 99 & 1.9 \pm 0.9 \\ 04 / 28 / 99 & 1.8 \pm 0.6 \\ 05 / 05 / 99 & 0.5 \pm 0.4 \\ 05 / 12 / 99 & 1.0 \pm 0.5 \\ 05 / 19 / 99 & 2.4 \pm 0.9 \\ 05 / 26 / 99 & 2.4 \pm 2.2 \\ 06 / 02 / 99 & 2.3 \pm 1.0 \\ 06 / 09 / 99 & 0.8 \pm 0.8 \\ 06 / 16 / 99 & 2.1 \pm 1.1 \\ 06 / 23 / 99 & 2.9 \pm 1.1 \\ 06 / 30 / 99 & 1.5 \pm 0.6\end{array}$

$\begin{array}{ll}\text { Mountain } & 04 / 07 / 99 \\ \text { View } & 04 / 14 / 99 \\ \text { Middle } & 04 / 21 / 99 \\ \text { School } & 04 / 28 / 99 \\ \text { (Replicate) } & 05 / 05 / 99 \\ & 05 / 12 / 99 \\ & 05 / 19 / 99 \\ & 05 / 26 / 99 \\ & 06 / 02 / 99 \\ & 06 / 09 / 99 \\ & 06 / 16 / 99 \\ & 06 / 23 / 99 \\ 06 / 30 / 99\end{array}$

Arco $\quad 04 / 07 / 99$

$04 / 14 / 99$
$1.1 \pm 0.5$

$1.0 \pm 0.5$
Gross Alpha Concentration $\pm 2 \mathrm{~s}$

$\left(\mu \mathrm{Ci} / \mathrm{ml} \times 10^{-15}\right)$
Gross Beta Concentration $\pm 2 \mathrm{~s}$ $\left(\mu \mathrm{Ci} / \mathrm{ml} \times 10^{-15}\right)$

$$
\begin{array}{r}
18 \pm 2 \\
24 \pm 3 \\
27 \pm 3 \\
23 \pm 2 \\
14 \pm 1 \\
19 \pm 2 \\
20 \pm 2 \\
15 \pm 1 \\
7 \pm 1 \\
17 \pm 2 \\
16 \pm 2 \\
25 \pm 4 \\
19 \pm 2 \\
16 \pm 2 \\
22 \pm 2 \\
24 \pm 2 \\
20 \pm 2
\end{array}
$$

Replicate Sampler

$\begin{array}{ll}1.9 \pm 0.5 & (1.4 \pm 0.5) \\ 1.9 \pm 0.6 & (1.4 \pm 0.6) \\ 2.6 \pm 0.9 & (1.7 \pm 1.0) \\ 1.9 \pm 0.6 & (1.9 \pm 0.6) \\ 0.4 \pm 0.4 & (0.4 \pm 0.4) \\ 1.2 \pm 0.5 & (1.9 \pm 0.7) \\ 1.2 \pm 0.8 & (2.4 \pm 1.1) \\ 2.0 \pm 0.9 & (2.3 \pm 1.0) \\ 1.7 \pm 0.9 & (3.0 \pm 1.2) \\ 1.0 \pm 0.7 & (1.5 \pm 1.0) \\ 1.9 \pm 0.9 & (1.0 \pm 1.0) \\ 3.1 \pm 0.9 & (1.6 \pm 1.0) \\ 1.4 \pm 0.6 & (2.3 \pm 0.8)\end{array}$

$14 \pm 1$

$17 \pm 1$

$22 \pm 2$

$15 \pm 1$

$7 \pm 1$

$16 \pm 2$

$16 \pm 2$

$22 \pm 2$

$20 \pm 2$

$13 \pm 2$

$22 \pm 2$

$25 \pm 2$

$18 \pm 2$

Replicate Sampler

$$
\begin{aligned}
& (13 \pm 1) \\
& (17 \pm 2) \\
& (20 \pm 2) \\
& (16 \pm 2) \\
& (9 \pm 1) \\
& (18 \pm 2) \\
& (18 \pm 2) \\
& (22 \pm 2) \\
& (19 \pm 2) \\
& (13 \pm 2) \\
& (23 \pm 2) \\
& (23 \pm 2) \\
& (20 \pm 2)
\end{aligned}
$$

$16 \pm 1$

$16 \pm 1$ 


\section{Appendix C \\ Weekly Gross Alpha and Gross Beta Concentrations in Air 2nd Quarter 1999}

Location Collection Date

$$
\begin{aligned}
& 04 / 21 / 99 \\
& 04 / 28 / 99 \\
& 05 / 05 / 99 \\
& 05 / 12 / 99 \\
& 05 / 19 / 99 \\
& 05 / 26 / 99 \\
& 06 / 02 / 99 \\
& 06 / 09 / 99 \\
& 06 / 16 / 99 \\
& 06 / 23 / 99 \\
& 06 / 30 / 99
\end{aligned}
$$

\begin{abstract}
Atomic City 04/07/99
(Replicate) 04/14/99

$04 / 21 / 99$

$04 / 28 / 99$

$05 / 05 / 99$

$05 / 12 / 99$

$05 / 19 / 99$

$05 / 26 / 99$

$06 / 02 / 99$

$06 / 09 / 99$

$06 / 16 / 99$

$06 / 23 / 99$

$06 / 30 / 99$
\end{abstract}

Howe $\quad \begin{aligned} & 04 / 07 / 99 \\ & 04 / 14 / 99 \\ & 04 / 21 / 99 \\ & 04 / 28 / 99 \\ & 05 / 05 / 99 \\ & 05 / 12 / 99 \\ & 05 / 19 / 99 \\ & 05 / 26 / 99 \\ & 06 / 02 / 99 \\ & 06 / 09 / 99\end{aligned}$

Gross Alpha Concentration $\pm 2 \mathrm{~s}$

$\left(\mu \mathrm{Ci} / \mathrm{ml} \mathrm{x}^{-15}\right)$

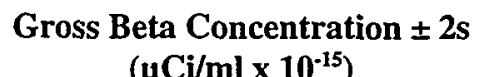

$21 \pm 2$

$19 \pm 2$

$8 \pm 1$

$19 \pm 2$

$15 \pm 2$

$23 \pm 2$

$18 \pm 2$

$13 \pm 2$

$21 \pm 2$

$23 \pm 2$

$19 \pm 2$

Replicate Sampler

$$
\begin{array}{ll}
0.6 \pm 0.4 & (0.4 \pm 0.3) \\
0.5 \pm 1.1 & (0.9 \pm 0.5) \\
1.2 \pm 0.9 & (2.1 \pm 0.9) \\
1.2 \pm 0.6 & (1.3 \pm 0.5) \\
0.2 \pm 0.4 & (0.2 \pm 0.3) \\
1.5 \pm 0.6 & (1.1 \pm 0.5) \\
1.6 \pm 0.9 & (1.6 \pm 0.8) \\
0.9 \pm 0.8 & (2.0 \pm 0.9) \\
1.7 \pm 0.9 & (1.2 \pm 0.8) \\
1.1 \pm 0.8 & (1.6 \pm 0.8) \\
1.2 \pm 0.9 & (1.0 \pm 0.8) \\
1.1 \pm 0.9 & (1.4 \pm 0.8) \\
1.2 \pm 0.5 & (1.1 \pm 0.5)
\end{array}
$$

$15 \pm 1$

$17 \pm 4$

$22 \pm 2$

$18 \pm 2$

$8 \pm 1$

$19 \pm 2$

$16 \pm 2$

$24 \pm 2$

$20 \pm 2$

$16 \pm 2$

$20 \pm 2$

$29 \pm 2$

$18 \pm 2$

$17 \pm 1$

$20 \pm 2$

$21 \pm 4$

$23 \pm 4$

$4 \pm 5$

$11 \pm 7$

$16 \pm 2$

$24 \pm 2$

$21 \pm 2$

$17 \pm 2$
Replicate Sampler

$$
\begin{array}{r}
(13 \pm 1) \\
(18 \pm 2) \\
(22 \pm 2) \\
(18 \pm 2) \\
(8 \pm 1) \\
(20 \pm 2) \\
(18 \pm 2) \\
(24 \pm 2) \\
(21 \pm 2) \\
(16 \pm 2) \\
(24 \pm 2) \\
(21 \pm 2) \\
(19 \pm 2)
\end{array}
$$

$$
\begin{array}{r}
1.4 \pm 0.5 \\
1.5 \pm 0.5 \\
1.6 \pm 2.0 \\
3.6 \pm 1.5 \\
0.6 \pm 2.0 \\
-0.8 \pm 2.2 \\
1.0 \pm 1.1 \\
1.1 \pm 0.9 \\
1.3 \pm 0.9 \\
0.4 \pm 0.7
\end{array}
$$




\section{Appendix C \\ Weekly Gross Alpha and Gross Beta Concentrations in Air 2nd Quarter 1999}

Location Collection Date

$06 / 16 / 99$
$06 / 23 / 99$
$06 / 30 / 99$

FAA 04/07/99

Tower $\quad 04 / 14 / 99$

$04 / 21 / 99$

$04 / 28 / 99$

$05 / 05 / 99$

$05 / 12 / 99$

$05 / 19 / 99$

$05 / 26 / 99$

$06 / 02 / 99$

$06 / 09 / 99$

$06 / 16 / 99$

$06 / 23 / 99$

$06 / 30 / 99$

$\begin{array}{rr}\text { Monteview } & 04 / 07 / 99 \\ 04 / 14 / 99 \\ 04 / 21 / 99 \\ 04 / 28 / 99 \\ 05 / 05 / 99 \\ 05 / 12 / 99 \\ 05 / 19 / 99 \\ 05 / 26 / 99 \\ 06 / 02 / 99 \\ 06 / 09 / 99 \\ 06 / 16 / 99 \\ 06 / 23 / 99 \\ 06 / 30 / 99\end{array}$

Mud $\quad 04 / 07 / 99$

Lake $\quad 04 / 14 / 99$

$04 / 21 / 99$

$04 / 28 / 99$

05/05/99
Gross Alpha Concentration $\pm 2 \mathrm{~s}$ $\left(\mu \mathrm{Ci} / \mathrm{ml} \times 10^{-15}\right)$

$$
\begin{aligned}
& 1.5 \pm 1.0 \\
& 1.5 \pm 1.0 \\
& 1.4 \pm 0.6
\end{aligned}
$$

$0.7 \pm 0.5$

$1.0 \pm 0.6$

$1.4 \pm 1.1$

$1.5 \pm 0.6$

$0.3 \pm 0.5$

$0.7 \pm 0.6$

$1.4 \pm 1.1$

$1.4 \pm 1.2$

$0.9 \pm 1.1$

$0.7 \pm 1.0$

$1.4 \pm 1.2$

$1.0 \pm 1.1$

$0.5 \pm 0.6$

$1.2 \pm 0.5$

$2.0 \pm 0.8$

$1.9 \pm 1.1$

$1.5 \pm 0.6$

$0.4 \pm 0.4$

$1.3 \pm 0.6$

$1.1 \pm 0.9$

$1.9 \pm 1.0$

$2.2 \pm 1.0$

$1.0 \pm 0.9$

$1.4 \pm 0.9$

$2.0 \pm 1.0$

$1.6 \pm 0.6$

$1.2 \pm 0.5$

$1.0 \pm 0.6$

$1.7 \pm 0.8$

$1.4 \pm 0.5$

$0.6 \pm 0.4$
Gross Beta Concentration $\pm 2 \mathrm{~s}$

$\left(\mu \mathrm{Ci} / \mathrm{ml} \mathrm{x} \mathrm{10^{-15 } )}\right.$ $\begin{aligned} & 22 \pm 2 \\ & 30 \pm 2 \\ & 20 \pm 2 \\ & 13 \pm 2 \\ & 18 \pm 2 \\ & 20 \pm 2 \\ & 18 \pm 2 \\ & 8 \pm 2 \\ & 18 \pm 2 \\ & 14 \pm 2 \\ & 26 \pm 3 \\ & 20 \pm 2 \\ & 16 \pm 2 \\ & 21 \pm 3 \\ & 23 \pm 3 \\ & 19 \pm 2\end{aligned}$

$17 \pm 2$

$17 \pm 2$

$21 \pm 2$

$21 \pm 2$

$7 \pm 1$

$19 \pm 2$

$16 \pm 2$

$25 \pm 2$

$19 \pm 2$

$17 \pm 2$

$24 \pm 2$

$25 \pm 2$

$20 \pm 2$

$15 \pm 1$

$17 \pm 2$

$19 \pm 2$

$16 \pm 1$

$8 \pm 1$ 


\section{Appendix $\mathbf{C}$ \\ Weekly Gross Alpha and Gross Beta Concentrations in Air 2nd Quarter 1999}

Location Collection Date

$$
\begin{aligned}
& 05 / 12 / 99 \\
& 05 / 19 / 99 \\
& 05 / 26 / 99 \\
& 06 / 02 / 99 \\
& 06 / 09 / 99 \\
& 06 / 16 / 99 \\
& 06 / 23 / 99 \\
& 06 / 30 / 99
\end{aligned}
$$

$\begin{array}{ll}\text { Reno } & 04 / 07 / 99 \\ \text { Ranch } & 04 / 14 / 99 \\ & 04 / 21 / 99 \\ & 04 / 28 / 99 \\ & 05 / 05 / 99 \\ & 05 / 12 / 99 \\ & 05 / 19 / 99 \\ 05 / 26 / 99 \\ 06 / 02 / 99 \\ 06 / 09 / 99 \\ 06 / 16 / 99 \\ 06 / 23 / 99 \\ 06 / 30 / 99\end{array}$

INEEL $\quad 04 / 07 / 99$

Main $\quad 04 / 14 / 99$

Gate $\quad 04 / 21 / 99$

$04 / 28 / 99$

$05 / 05 / 99$

$05 / 12 / 99$

$05 / 19 / 99$

$05 / 26 / 99$

$06 / 02 / 99$

$06 / 09 / 99$

$06 / 16 / 99$

$06 / 23 / 99$

$06 / 30 / 99$
Gross Alpha Concentration $\pm 2 \mathrm{~s}$

$\left(\mu \mathrm{Ci} / \mathrm{ml} \times 10^{-15}\right)$
Gross Beta Concentration $\pm 2 \mathrm{~s}$ $\left(\mu \mathrm{Ci} / \mathrm{ml} \mathbf{1 0}^{-15}\right)$

$$
\begin{aligned}
& 1.6 \pm 0.6 \\
& 1.2 \pm 0.8 \\
& 1.6 \pm 1.0 \\
& 1.8 \pm 0.8 \\
& 1.0 \pm 0.8 \\
& 1.4 \pm 0.8 \\
& 1.2 \pm 0.9 \\
& 1.6 \pm 0.6
\end{aligned}
$$

$0.6 \pm 0.4$

$1.0 \pm 0.6$

$1.4 \pm 1.0$

$1.5 \pm 0.6$

$0.2 \pm 0.4$

$1.2 \pm 0.6$

$0.9 \pm 1.0$

$0.9 \pm 1.0$

$1.2 \pm 1.0$

$1.2 \pm 1.0$

$2.0 \pm 1.2$

$1.2 \pm 1.0$

$1.1 \pm 0.7$

$1.0 \pm 0.4$

$0.8 \pm 0.4$

$1.6 \pm 0.8$

$1.1 \pm 0.4$

$0.3 \pm 0.3$

$1.3 \pm 0.5$

$0.9 \pm 0.7$

$1.4 \pm 0.8$

$1.5 \pm 0.8$

$1.1 \pm 0.7$

$0.5 \pm 0.7$

$0.4 \pm 0.7$

$1.0 \pm 0.5$
$20 \pm 2$

$15 \pm 2$

$23 \pm 2$

$21 \pm 2$

$15 \pm 2$

$21 \pm 2$

$22 \pm 2$

$19 \pm 2$

$14 \pm 2$

$18 \pm 2$

$19 \pm 2$

$18 \pm 2$

$8 \pm 1$

$20 \pm 2$

$14 \pm 2$

$25 \pm 2$

$20 \pm 2$

$17 \pm 2$

$20 \pm 2$

$25 \pm 2$

$21 \pm 2$

$16 \pm 1$

$19 \pm 1$

$20 \pm 2$

$16 \pm 1$

$8 \pm 1$

$19 \pm 2$

$16 \pm 2$

$26 \pm 2$

$20 \pm 2$

$16 \pm 2$

$22 \pm 2$

$25 \pm 2$

$20 \pm 2$ 


\section{Appendix C \\ Weekly Gross Alpha and Gross Beta Concentrations in Air 2nd Quarter 1999}

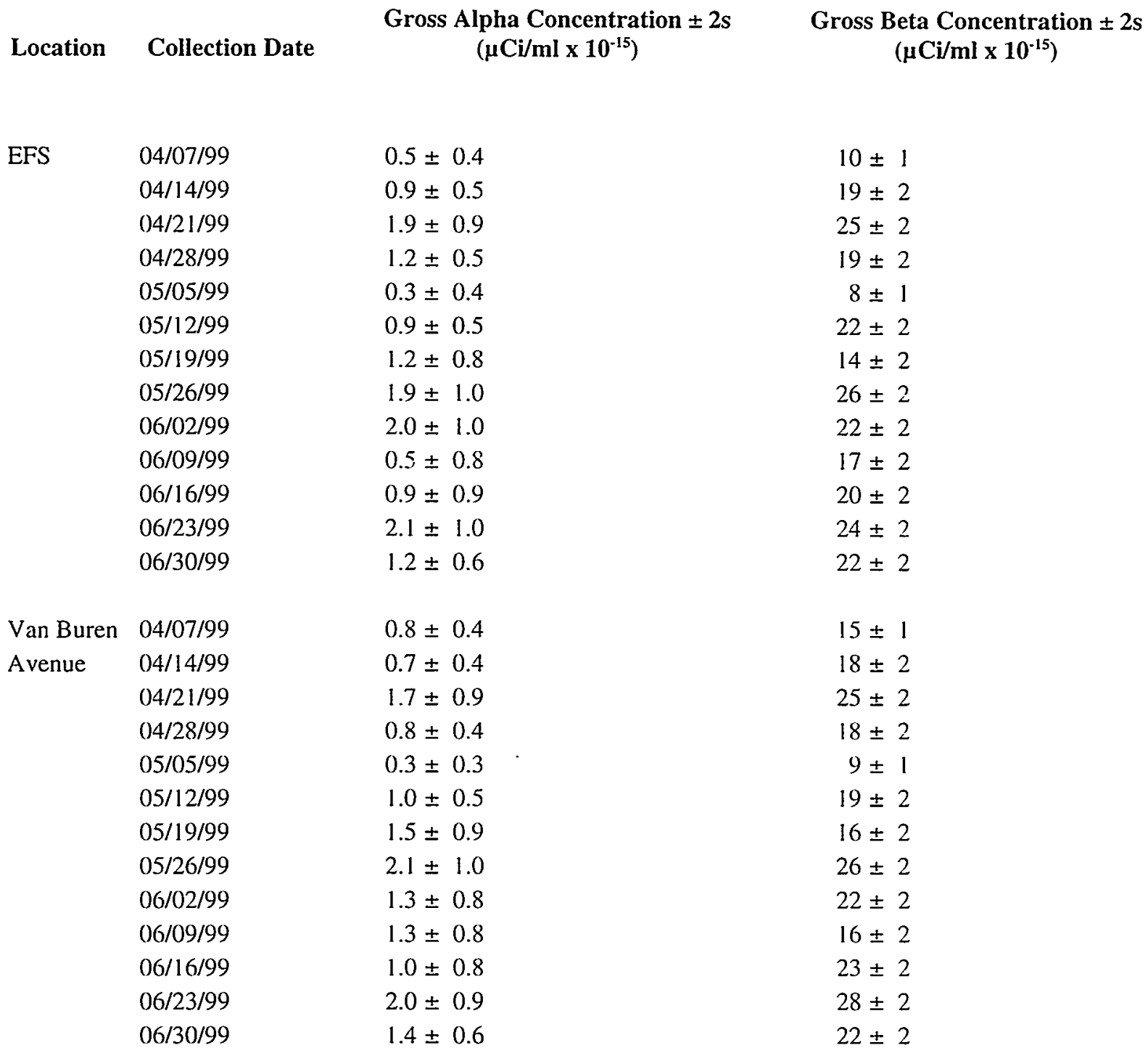

